\title{
Probabilistic Analysis of the Reliability Performance for Power Transformers in Egypt
}

\author{
${ }^{1}$ Ahmed El-Bassiouny, ${ }^{2}$ Mohamed El-Shimy, ${ }^{3}$ Rizk Hamouda \\ ${ }^{1}$ Salah Shaaban consulting office, Cairo, Egypt, \\ ${ }^{2}$ Electrical Power and Machines Department, Faulty of Engineering, Ain Shams University, Cairo, Egypt, \\ ${ }^{3}$ Energy Engineering, Faulty of Engineering, Heliopolis University, Cairo, Egypt, \\ ${ }^{1}$ mohamed_bekhet@eng.asu.edu.eg
}

\begin{abstract}
From reliability, maintainability, and availability (RAM) points of view, the performance of power transformers has significant impacts on the performance of the entire power network. Their performance has also significant impacts on the power interruptions at various voltage levels and the consequent customer interruption costs. This paper I discusses the estimated remaining lifetime of power transformers in $500 \mathrm{kV}, 220 \mathrm{kV}, 132 \mathrm{kV}$ and $66-33 \mathrm{kV}$ subpopulations of the Egyptian grid in which the best fit probability distribution is used through MATLAB program as the input data is time between failures (TBFs). The best fit probability distribution is used in this case study which is Weibull distribution. Finally, availability of the transformers per different voltage populations is calculated. Different subassemblies (failures) are also subjected to the same process of determining TBFs and estimating remaining lifetime. The results are helpful in the manufacturing process of the transformers and enhancing the maintenance schedule.
\end{abstract}

Keywords - Transformers, Weibull distribution, Remaining lifetime, Availability.

\section{INTRODUCTION}

This paper discusses the probabilistic analysis of the reliability performance for the transformers of different voltage populations of the Egyptian Power Grid so that failure rates are calculated. Based on this, the overall performance of the transformer shall be observed. All the analyses are performed under probabilistic approach. The probabilistic analysis accounts for the uncertainties in the input data. The best fits of statistical probability distributions are determined for each transformer and for each of its subassemblies in various voltages subpopulations.

Main Data, collected of the Egyptian power grid from [1]-[3], are the number of transformers, number of failures, and repair time for every voltage subpopulation which are $500 \mathrm{kV}, 220 \mathrm{kV}, 132 \mathrm{kV}$ and
66-33 kV of the Egyptian power grid from the year 2002 till 2009. The statistical approach is performed by using MATLAB program. Different continuous probability distributions were compared in order to obtain the best fit distribution for this case study. The input data is time between failures (TBFs) and Weibull distribution is used as a main distribution in this paper because it is widely and commonly used in reliability and lifetime analysis $[4,5,6]$.

Remaining life time of the transformers in different voltage subpopulations are estimated by using the probability distributions and the results from the distributions will also be compared. Using Weibull distribution usually requires a defined failure time which is the time from the start of operation till failure occurred. Since the study period is only 8 years from year 2002 till year 2009, therefore time between failures (TBFs) is used in this paper since the TBFs units are years.

\section{PROBABILITY DISTRIBUTIONS}

Probability distributions are a mathematical method used to measure and analyze random variables [7]. Reliability engineering provides the methods and tools used to estimate the life time of equipment or components without failure for a specific period of time [8]. Probability distributions are categorized into continuous probability distributions and discrete probability distributions [9]. The selection of the most suitable probability distribution depends on every case. In this paper, since data are positive numbers and continuous, the selected distributions are Weibull distribution, Normal distribution, Rayleigh distribution, Logistic distribution and Lognormal distribution. Table (1) gives a summary regarding the five selected distributions. 
Table 1 Summary of Five Different Probability Distributions.

\begin{tabular}{|c|c|c|c|}
\hline & $\begin{array}{l}\text { Probability } \\
\text { Distribution }\end{array}$ & Type & Characteristics \\
\hline 1 & $\begin{array}{c}\text { Normal } \\
\text { (Gaussian) }\end{array}$ & Continuous & $\begin{array}{l}\text { It is used in reliability } \\
\qquad f(t)=\frac{1}{\sqrt{2} \pi \sigma} \mathrm{e}^{\frac{-1}{2}\left(\frac{t-\mu}{\sigma}\right)^{2}} \\
\text { Where } \mu \text { is the mean } \\
\sigma \text { is the standard deviation }\end{array}$ \\
\hline 2 & Logistic & Continuous & $\begin{array}{l}\text { It is used to describe growth, that is, the size of a population expressed as a } \\
\text { function of a time variable } \\
\qquad f(t)=\frac{\mathrm{e}^{\frac{\mu-x}{\alpha}}}{\alpha\left[1+\mathrm{e}^{\frac{\mu-x}{\alpha}}\right]} \\
\mu \text { is the mean or location parameter } \\
\alpha \text { is scale parameter }\end{array}$ \\
\hline 3 & Weibull & Continuous & $\begin{array}{l}\text { Used in reliability } \\
\qquad f(t)=\frac{\beta}{\eta} *\left(\frac{t}{\eta}\right)^{\beta-1} * e^{-\left(\frac{t}{\eta}\right)^{\beta}} \\
\beta \text { is shape parameter } \\
\eta \text { is scale parameter }\end{array}$ \\
\hline 4 & Lognormal & Continuous & $\begin{array}{l}\text { It is used in Life time modelling and very helpful in Reliability engineering } \\
\qquad f(t)=\frac{1}{\sqrt{2} \pi * \sigma^{\prime}} e^{\frac{-1}{2}\left(\frac{t \prime-\mu \prime}{\sigma^{\prime}}\right)^{2}} \\
\mathrm{t}^{\prime}=\ln (\mathrm{t}) \\
\mu^{\prime} \text { is the mean of Log time to fail } \\
\sigma^{\prime} \text { is the standard deviation of log time to fail }\end{array}$ \\
\hline 5 & Rayleigh & Continuous & $\begin{array}{l}\quad f(t)=2 * \alpha * \lambda^{2} * t * e^{-(\lambda * t)^{2}} *\left(1-e^{-(\lambda * t)^{2}}\right)^{\alpha-1} \\
\alpha \text { shape parameter } \\
\lambda \text { scale parameter }\end{array}$ \\
\hline
\end{tabular}

2. A. Data Analysis and Remaining Lifetime Estimate of the Transformer

\section{A. TBFs calculations}

TBFs calculations for different voltage subpopulations are performed. All calculations are per transformer per year per failure. Figure (1) shows the different TBFs values for every voltage subpopulation where TBFs decrease as time increases indicating an increase in the failure rate. In comparison between different voltage subpopulations, $132 \mathrm{kV}$ population has the highest TBF among the different voltage populations followed by $500 \mathrm{kV}$ then $66-33 \mathrm{kV}$ and finally $220 \mathrm{kV}$. These differences in TBFs between different voltages populations due to the fact that every sub voltage population has its own collected data.

\section{B. Best fit distribution TBFs}

After calculating TBFs, the second step is to determine the best suitable distribution by making a comparison between 5 different continuous distributions which are: Weibull distribution, Normal distribution, Rayleigh distribution, Logistic distribution, and Lognormal distribution. After getting Statistical mean and standard deviation results from MATLAB program, a percentage (\%) difference of the mean and Standard Deviation (STD) is made between arithmetic and statistical values.

Normal distribution is a flexible distribution that fits parameters according to given values where the distribution is always symmetrical around the mean and mean, median and mode are always the same results $[4,10]$. Accordingly, the Normal distribution is used in comparison and in obtaining the deterministic values only not in the ranking of the best fit distribution.

Table 2 summarizes the findings and indicates the best fit probability distribution in this case study. From the comparison between the distributions, Weibull distribution is common for all voltages subpopulations. This concludes that Weibull distribution is suitable for 
this case study. The second common distribution used is Lognormal distribution followed by Logistic distribution.

As per [5], the years with zero values shall be omitted from the population regarding Weibull distribution and as for Rayleigh distribution, it is a special deviation of Weibull distribution $[11,12]$ thus population with zero values are omitted, too. Therefore, for fair comparison, the study period is shortened and the results were obtained on this fact.

Weibull distribution acts as the main probability distribution in this paper in estimating the remaining life time of transformer. However, the Weibull distribution is under the investigation as like the other 4 probability distributions. This does not mean that Weibull distribution is not used in lifetime calculation, but it could not be suitable for this case only, also Weibull distribution has proven a high efficiency in lifetime analysis [13, 14].

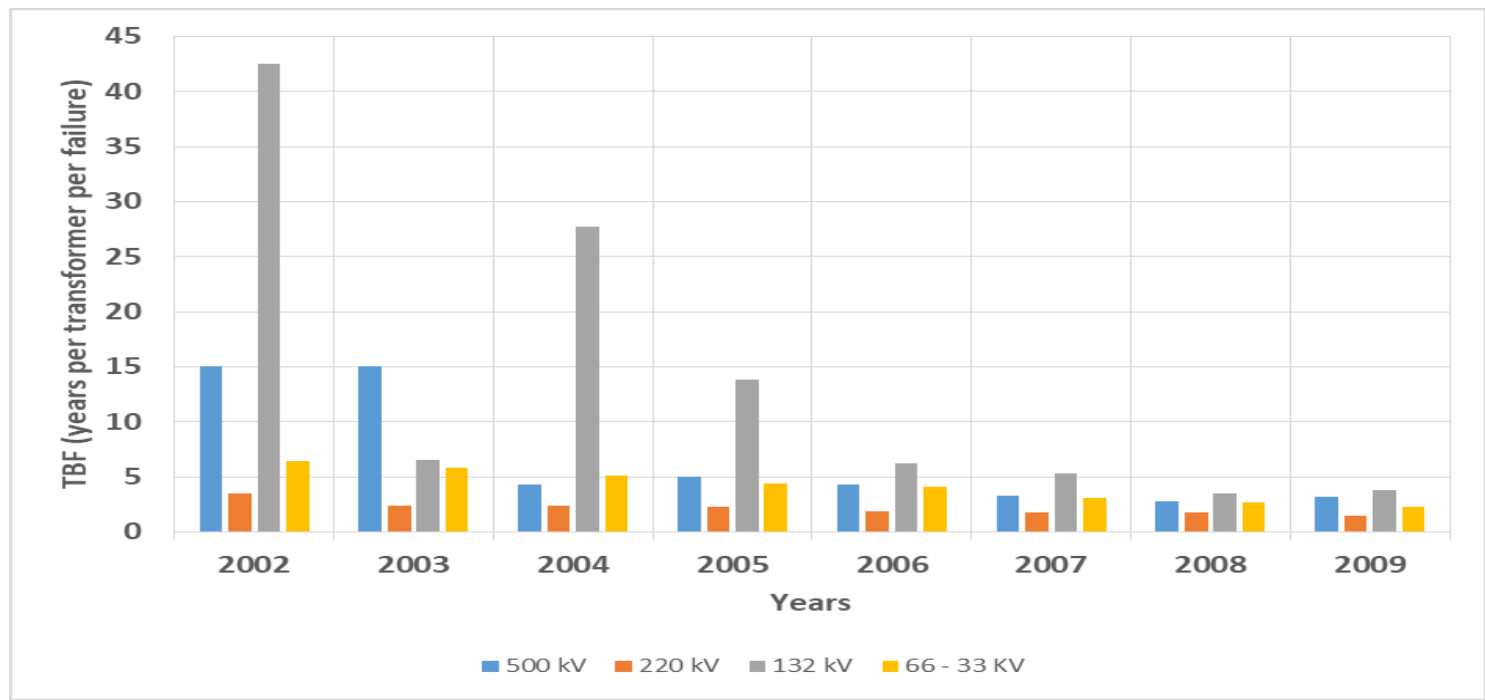

Fig .1 TBFs for different voltage populations

Table 2 Summary Table Indicating Best Fit Distributions for Every Voltage Subpopulation

\begin{tabular}{|c|c|}
\hline \multirow{2}{*}{$\begin{array}{c}\text { Voltage } \\
\text { Subpopulation }\end{array}$} & Probability Distribution used \\
\cline { 2 - 2 } & TBFs \\
\hline $500 \mathrm{kV}$ & Lognormal \& Weibull \\
\hline $220 \mathrm{kV}$ & Weibull \& Lognormal \\
\hline $132 \mathrm{kV}$ & Weibull \& Lognormal \\
\hline $66-33 \mathrm{kV}$ & Weibull \& Logistic \\
\hline
\end{tabular}

\section{ESTIMATING THE REMAINING LIFETIME OF THE TRANSFORMERS}

The study period is 8 years from the year 2002 to year 2009 and by using probability distributions as in table 2, TBFs will be the main input to the distributions in order to predict the remaining lifetime of the transformers. MATLAB program is used in the analysis where distribution fitter application in MATLAB is a very useful tool for the analysis. As for Weibull distribution, parameters estimation in MATLAB coding is by the method of Maximum Likelihood Estimation
$[15,16]$ where this method is the most advanced and accurate method to determine the parameters.

\section{A. $500 \mathrm{kV}$ Subpopulation Transformers}

From table 2, Lognormal distribution and Weibull distribution are used in determining the remaining lifetime of this voltage subpopulation where TBF is the input data to the two distributions and the output will be failure rate and Reliability, respectively.

Figure 2, represents the failure rate where it is clear that failure rate increases by time, this concurs with $B$ is greater than 1 and failure rate increases by time, while, on the other hand, the failure rate of the Lognormal distribution increases till it reaches the peak values and then decreases by time [6, 10, 17]. Figure 3 , represents the reliability of the transformers and remaining life time can be obtained at certain reliability rates. Reliability rates depend on the geographical factor; for example, area with industrial complexes may require a high-level reliability other than different areas. 


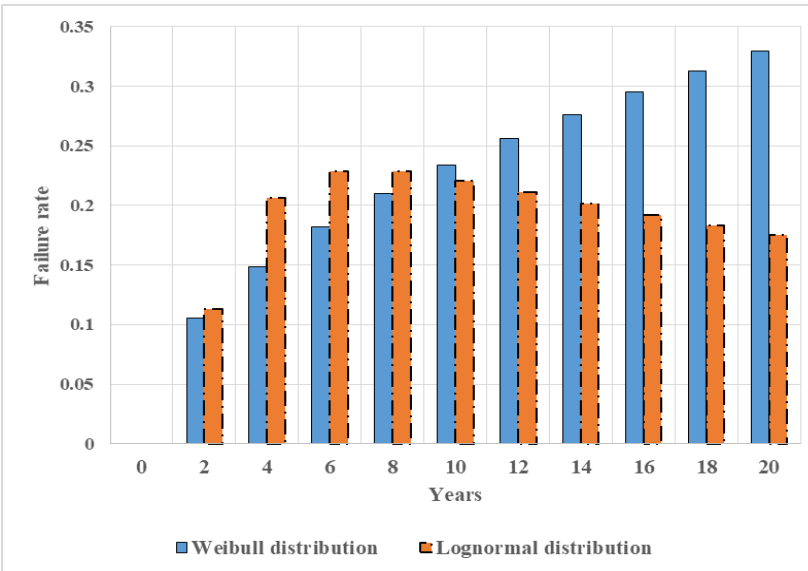

Fig .2 Failure rates of different probability distributions for 500 $k V$ subpopulation

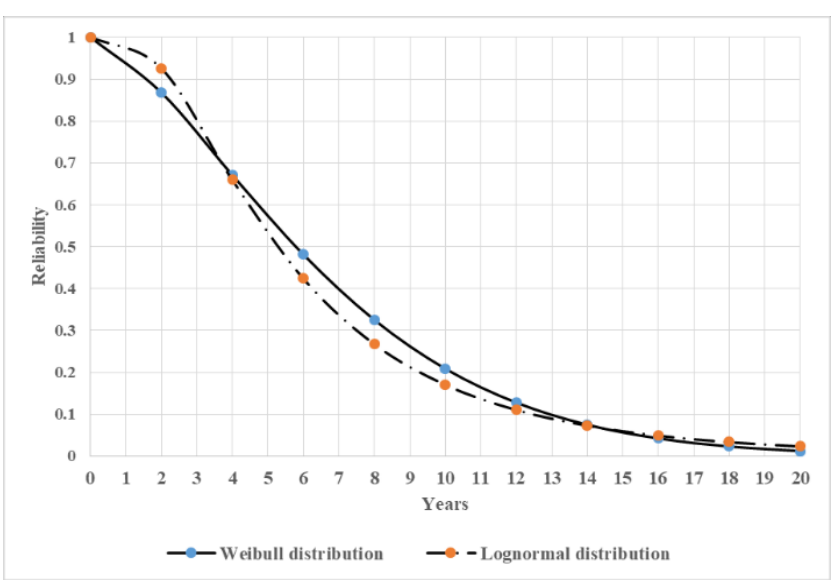

Fig .3 Reliability of different probability distributions for $500 \mathrm{kV}$ subpopulation

\section{B. 220 kV Subpopulation Transformers}

This section focuses on $220 \mathrm{kV}$ population transformers reliability and remaining life time through the same steps that were used in the $500-\mathrm{kV}$ population.

Figure 4 indicates that failure rate regarding Weibull distribution increases rapidly by time while failure rate of Lognormal distribution reaches its peak at 4 years thus leads to the conclusion that the transformers must be replaced. Figure 5 illustrates the reliability through 4 years in which the remaining life time of the transformers is exploited.

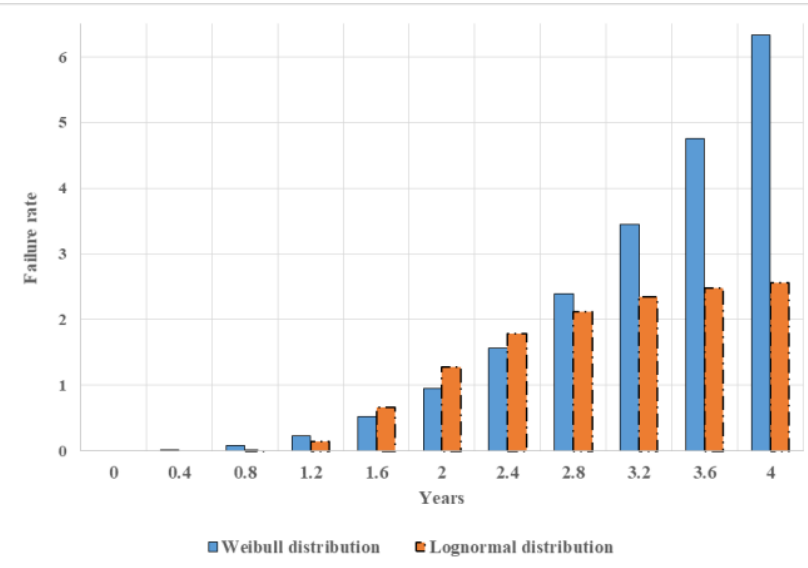

Fig .4 Failure rates of different probability distributions for 220 kV subpopulation

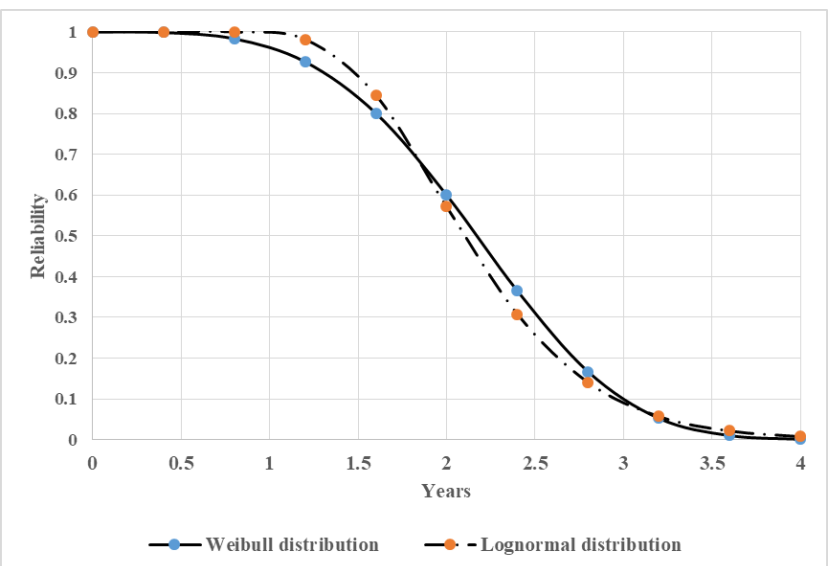

Fig .5 Reliability of different probability distributions for $220 \mathrm{kV}$ subpopulation

\section{C. $132 \mathrm{kV}$ Subpopulation Transformers}

This section focuses on $132 \mathrm{kV}$ population transformers reliability and remaining life time through the same steps that were previously used in the 500 $\mathrm{kV}$ and $220 \mathrm{kV}$ populations.

Figure 6 shows that the failure rate increases by time regarding Weibull distribution, but it increases at slow rate while. On the other hand, the curve of the failure rate resulting from lognormal distribution started from peak and then decreases by time. Figure 7 shows that the reliability of both distributions in 50 years life span and reliability decreases gradually. However, reliability of Lognormal distribution decreases faster than that of Weibull distribution. 


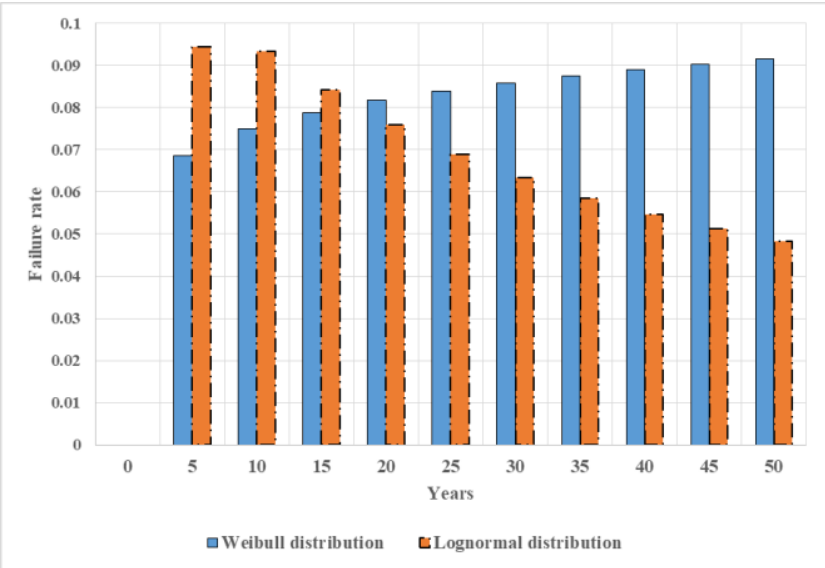

Fig .6 Failure rates of different probability distributions for 132 $\mathrm{kV}$ subpopulation.

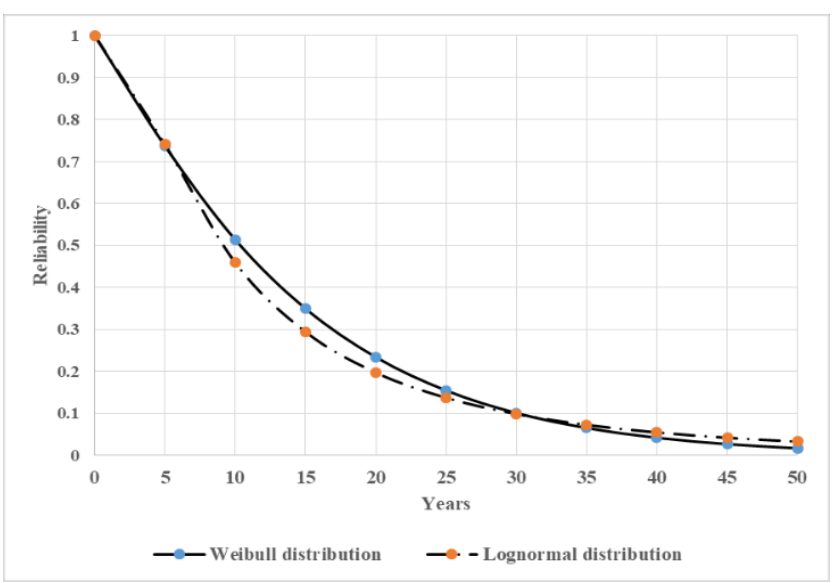

Fig .7 Reliability of different probability distributions for $132 \mathrm{kV}$ subpopulation.

\section{66-33 kV Subpopulation Transformers}

This section focuses on 66-33 kV population transformers reliability and remaining life time where the same steps that were used in the $500 \mathrm{kV}, 220 \mathrm{kV}$ and $132 \mathrm{kV}$ populations are reused again. However, this is the only population that has used Logistic distribution instead of Lognormal distribution along with Weibull distribution based on the comparison of best fit distributions.

Figure 8 shows that failure rates of both distributions increase by time, this indicates that the transformers are in the wear out phase where failure rate increases rapidly regarding Weibull distribution and increases in a slow rate regarding Logistic distribution. Figure 9 shows that it is clear that reliability was decreasing slowly in the first 2 years then falls back till it reaches zero nearly at 8 years period of time and the transformers remaining life time can be obtained at certain reliability rates.

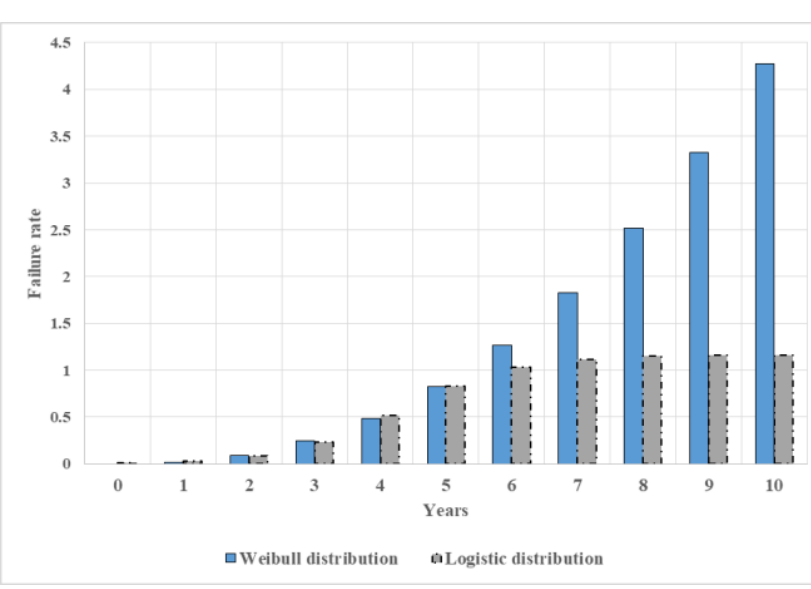

Fig .8 Failure rates of different probability distributions for $66-33$ $\mathrm{kV}$ subpopulation.

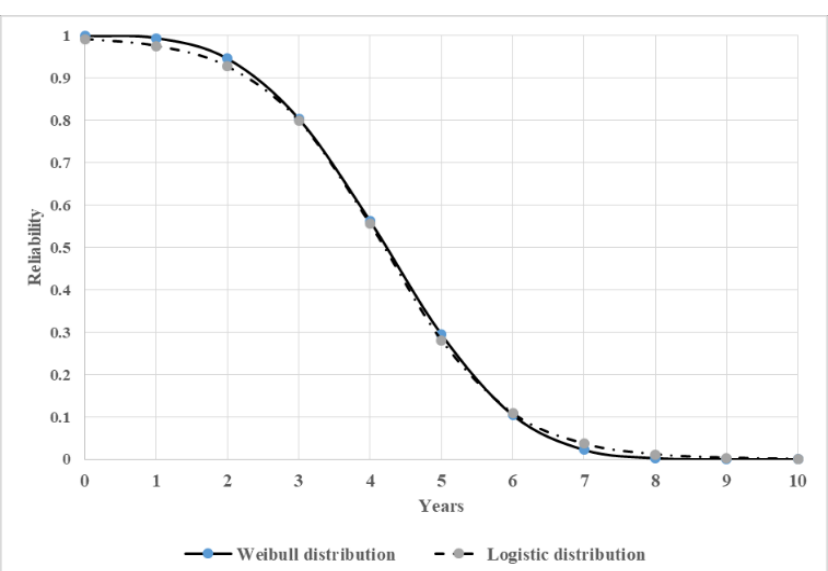

Fig .9 Reliability of different probability distributions for $66-33 \mathrm{kV}$ subpopulation.

\section{E. Transformers Availability Evaluation}

This section discusses the availability (A) of the transformers of different voltage populations as availability can be calculated from (1) after determining TBFs and TTR as listed in appendix C [18]-[20].

$A=\frac{T B F S}{T B F S+T T R}$

Since (1) is per year, therefore for the whole 8 years study period, the mean time between failures (MTBF) and mean time to repair (MTTR) is used as in (2) .

$A=\frac{M T B F S}{M T B F S+M T T R}$

Figure 10 illustrates the different availability per year and for the overall study period for different voltage populations. In general, availability is high despite the increased failure rates and limited expected lifetime of transformers per voltage populations. From (2), the 
calculation for different voltage populations determined that $500 \mathrm{kV}$ population has the lowest availability followed by $220 \mathrm{kV}$ then $132 \mathrm{kV}$ and finally 66-33 kV.

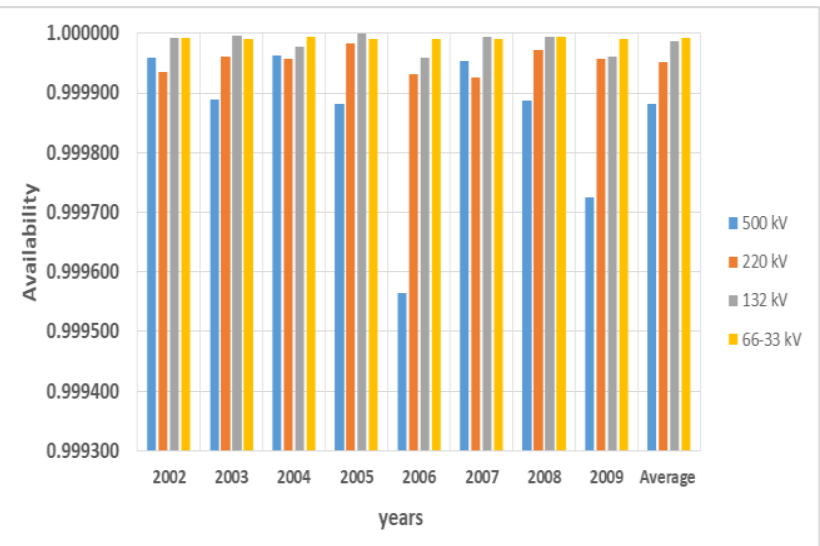

Fig 10 Different availability of different voltages population.

\section{F. Results Discussion.}

The results were based on 8 years study period and of course the longer the years the better the results will be, as transformers life span cab be of average 40-60 years $[21,22]$. The results indicate that the transformers are in the wear-out phase of the bathtub curve for all voltage populations. Bathtub curve is a curve that describes 3 stages of any equipment. The first stage is the infant phase where the equipment starts operation for the first time with a low failure rate and high reliability. The second stage is the useful life phase where the failure rate is constant. The final phase is the wear-out phase in which the equipment operates for a long time, starts to fail at a certain point and needs replacing. In this phase, the failure rate increases and reliability decreases [4].

The remaining lifetime of the transformers for every voltage subpopulation is summarized in table 3 where the transformers in all voltages subpopulation must be replaced within few years with new transformers in order to deliver a higher reliability to the Egyptian power grid. Since Weibull distribution is common between all populations and is based on percentage difference of mean and STD, it is chosen to observe the remaining life time, where it is found that the remaining life span of the transformers in all populations is nearly alike and that the transformers will be expired with this range of years as shown in table (3). Choosing different reliability levels depends on the operator, while these voltage populations must have a high reliability level as these voltage populations exist in the transmission power system that delivers the generated electrical power to the distribution systems (low voltage system), thus these voltages are the only link between generation and distribution.

From the results, instructions can be delivered to the maintenance department in order to perform a proper maintenance schedule and to the operation department in order to operate and handle the transformers carefully. In addition, the results shall be sent to the manufacturer so that transformers with better components and with higher quality and technology are manufactured. This will lead to lowering the interruption power and lower repair time and customer interruption costs in which the costs were highly based on an earlier study of the same period of time to the transformers.

Table 3 Remaining Lifetime in Comparison between Different Voltage Populations.

\begin{tabular}{|c|c|c|c|c|}
\hline $\begin{array}{l}\text { Voltage } \\
\text { Population } \\
\text { Remaining } \\
\text { Lifetime } \\
\text { in Years }\end{array}$ & $\begin{array}{l}500 \\
k V\end{array}$ & $\begin{array}{l}220 \\
k V\end{array}$ & $\begin{array}{l}132 \\
k V\end{array}$ & $\begin{array}{c}66-33 \\
k V\end{array}$ \\
\hline $\begin{array}{l}\text { Weibull distribution at } \\
90 \% \text { Reliability level }\end{array}$ & $\begin{array}{c}1.6 \\
\text { years }\end{array}$ & $\begin{array}{c}1.3 \\
\text { years }\end{array}$ & $\begin{array}{c}2 \\
\text { years }\end{array}$ & $\begin{array}{c}2.4 \\
\text { years }\end{array}$ \\
\hline $\begin{array}{l}\text { Weibull distribution at } \\
80 \% \text { Reliability level }\end{array}$ & $\begin{array}{c}2.7 \\
\text { years }\end{array}$ & $\begin{array}{c}1.6 \\
\text { years }\end{array}$ & $\begin{array}{c}3.75 \\
\text { years }\end{array}$ & $\begin{array}{c}3 \\
\text { years }\end{array}$ \\
\hline $\begin{array}{l}\text { Weibull distribution at } \\
70 \% \text { Reliability level }\end{array}$ & $\begin{array}{c}3.7 \\
\text { years }\end{array}$ & $\begin{array}{c}1.8 \\
\text { years }\end{array}$ & $\begin{array}{l}5.75 \\
\text { years }\end{array}$ & $\begin{array}{c}3.45 \\
\text { years }\end{array}$ \\
\hline
\end{tabular}

\section{G. Subassemblies Data Analysis.}

As transformers are the most important equipment in the power system, analysis of their function, maintenance and observation reports are taken into consideration by the manufactures in order to deliver a much higher quality next generation transformers. $[23,24]$ mentioned the basis of the transformers design, protection, operation and maintenance.

There are 16 subassemblies of failures in which the analysis is applied [1]-[3]. These failures are sometimes referred to as outage causes and categorized into five categories which are transformer related outages, power system related outages, environment related outages, human factor related outages (HM), and unclassified/No flag (NF) and other 
outage causes. The transformer related outages are Buchholz and pressure relief (B\&P), over current protection (OC), earth fault protection (EFP), differential protection (DP), breakdown and damage (B\&D), firefighting system (FFS), hotspots (HS), leakage of SF6 or oil (leakage), and flash over (FO). The power system related outage category includes the outage of incomers (OI), and bus bar protection (BBP) actions. The environment related outage category includes bad weather (BW), and animal and birds (A\&B) caused outages

\section{A. Estimation of Remaining Lifetime for Each of the Subassemblies}

Similar to the steps taken in order to estimate the remaining lifetime of the transformers, TBFs of different subassemblies are calculated and listed in table 4. Then the mean time between failures for every subassembly will be determined and compared to the mean time between failures for the whole transformer for different voltage populations. Finally, the remaining lifetime for every subassembly is estimated using Weibull distribution.

Table 4 and Figure 11 compare between MTBFs for every subassembly and for different voltage populations. It is clear that there is no direct relation between the overall MTBFs of the transformers as a complete set and the different subassemblies. A comparison is made to determine the Maximum and Minimum MTBFs for every subassembly for different voltage populations as shown in table 5 . This comparison is made by excluding NF and other failures as they are not physical but undetermined failures. Table 5 also shows that that every voltage population has a different maximum and minimum values regarding MTBFs depending on number of failures and repair time.

Table 4 TBFs for Every Subassemblies Regarding 500 kV Population.

\begin{tabular}{|c|c|c|c|c|}
\hline Voltage Populations & $500 \mathrm{kV}$ & $220 \mathrm{kV}$ & $132 \mathrm{kV}$ & $66-33 \mathrm{kV}$ \\
\hline & $\begin{array}{c}\text { Mean } \\
\text { Values }\end{array}$ & $\begin{array}{c}\text { Mean } \\
\text { Values }\end{array}$ & $\begin{array}{c}\text { Mean } \\
\text { Values }\end{array}$ & $\begin{array}{l}\text { Mean } \\
\text { Values }\end{array}$ \\
\hline $\begin{array}{l}\text { TBF for whole } \\
\text { transformer }\end{array}$ & 6.60 & 2.17 & 13.67 & 4.22 \\
\hline TBF for B\&P & 1.33 & 71.99 & 9.88 & 86.42 \\
\hline TBF for OC & 9.38 & 11.50 & 22.93 & 19.28 \\
\hline TBF for EFP & 13.25 & 54.13 & 36.13 & 45.49 \\
\hline TBF for DP & 13.25 & 21.21 & 34.42 & 37.19 \\
\hline TBF for $B \& D$ & 15.00 & 39.31 & 28.69 & 62.72 \\
\hline TBF for FFS & 15.25 & 106.5 & 10.63 & 340.2 \\
\hline TBF for HS & 0.00 & 95.07 & 0.00 & 0.00 \\
\hline TBF for Leakage & 7.63 & 22.14 & 8.27 & 0.00 \\
\hline TBF for FO & 0.00 & 77.00 & 0.00 & 0.00 \\
\hline TBF for OI & 0.00 & 73.46 & 18.71 & 15.01 \\
\hline TBF for BBP & 3.75 & 86.59 & 3.33 & 438.5 \\
\hline TBF for BW & 7.50 & 92.46 & 3.54 & 580.4 \\
\hline TBF for $A \& B$ & 0.00 & 106.7 & 34.50 & 582.9 \\
\hline TBF for $\mathrm{HM}$ & 0.00 & 34.09 & 5.19 & 735.3 \\
\hline TBF for NF & 5.63 & 76.81 & 10.00 & 134.4 \\
\hline TBF for Others & 15.75 & 15.63 & 13.16 & 197.6 \\
\hline
\end{tabular}




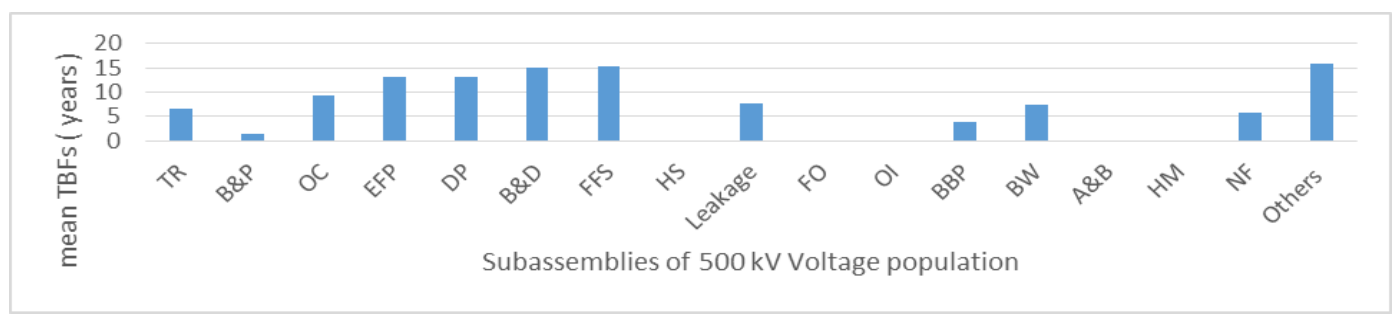

Fig . 11a. MTBFs for every subassembly regarding $500 \mathrm{kV}$ population.

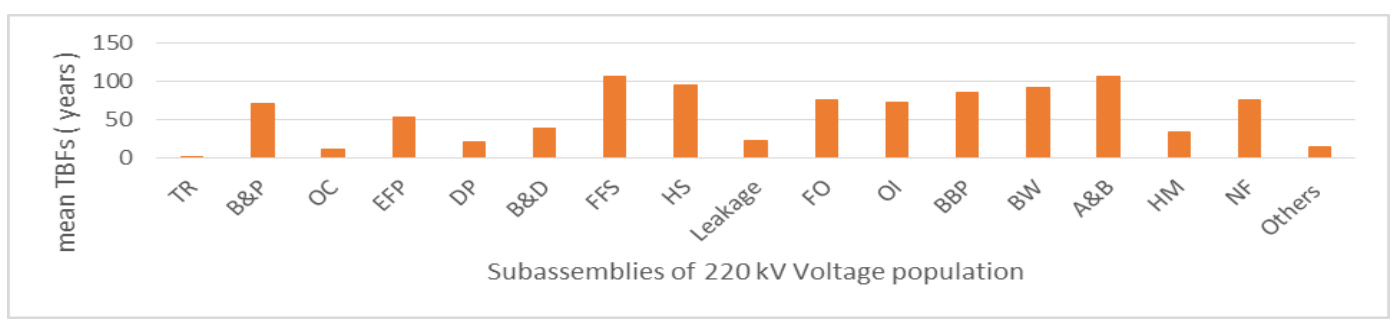

Fig . 11b. MTBFs for every subassembly regarding $220 \mathrm{kV}$ population.

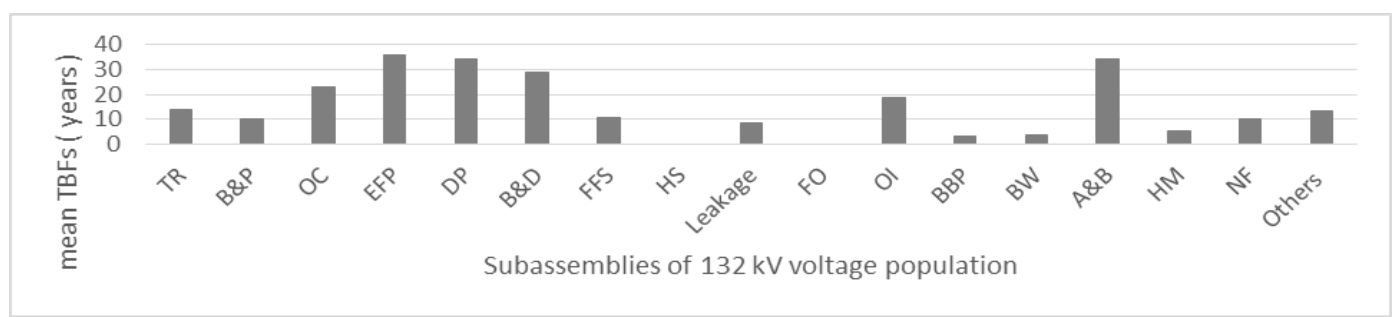

Fig . 11c. MTBFs for every subassembly regarding $132 \mathrm{kV}$ population.

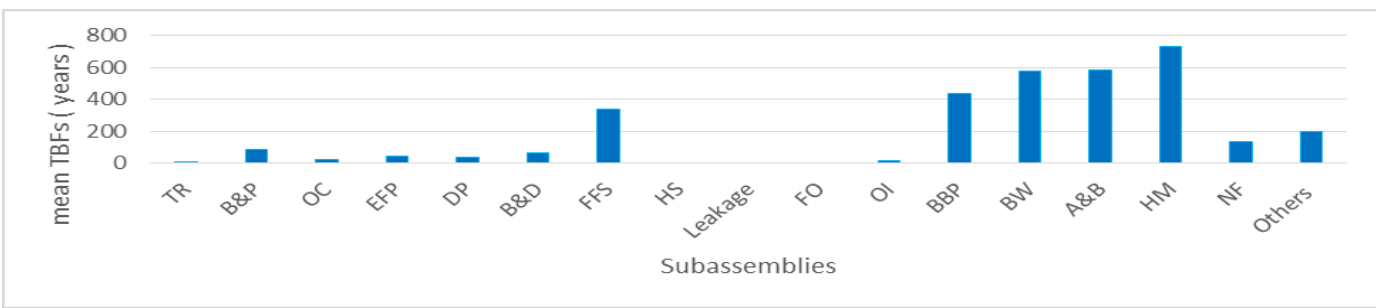

Fig . 11d. MTBFs for every subassembly regarding 66-33 kV population.

Table 5 Maximum and Minimum MTBFs for Different Voltage Population.
\begin{tabular}{|c|c|c|c|c|}
\hline & $\mathbf{5 0 0} \mathbf{~ k V}$ & $\mathbf{2 2 0} \mathbf{~ k V}$ & $\mathbf{1 3 2} \mathbf{~ k V}$ & $\mathbf{6 6 - 3 3} \mathbf{~ k V}$ \\
\hline Maximum MTBFs & B\&D & FFS & EFP & HM \\
\hline Minimum MTBFs & B\&P & OC & BBP & OI \\
\hline
\end{tabular}

\section{B. Results Discussion}

The overall TBF of the whole transformer does not depend on the TBF of every subassembly. In fact, every subassembly has its own TBF that depends on different variables. For every subassembly, the components can be used for other purposes after the shutdown of the transformer such as bus bars, as bars can be recycled into new ones, or in case the failure did not affect their functionality. As shown in Figure 11, a comparison between different voltage populations is performed in order to check the MTBF among different subassemblies where MTBF differs from voltage population to another as it depends on the number of failures and the number of transformers. MTBFs indicates that the failure rate decreases as MTBF increases and vice versa as the TBFs decreases the failure rate increases.

Number of Failures, repair time and CIC per transformer analysis can provide solid data in order to improve maintenance schedules, inform the transformers' manufactures to enhance the quality of materials by performing more tests and offering training courses to the employees to reduce human error.

\section{CONCLUSIONS}

This paper handled RAM analysis for the transformers of different voltage populations in the Egyptian power grid and the results showed that the transformers are 

http://dx.doi.org/10.21622/RESD.2019.05.2.046

in the wear out phase but the availability of the process and train more personals.

transformers is high. This leads to enhancing maintenance schedules, improve the manufacturing

Table 6 Remaining Lifetime for Every Subassembly in Different Voltage Populations.

\begin{tabular}{|c|c|c|c|c|c|c|c|}
\hline \multicolumn{2}{|c|}{$500 \mathrm{kV}$} & \multicolumn{2}{|c|}{$220 \mathrm{kV}$} & \multicolumn{2}{|c|}{$132 \mathrm{kV}$} & \multicolumn{2}{|c|}{$66-33 \mathrm{kV}$} \\
\hline Subassembly & $\begin{array}{l}\text { Remaining } \\
\text { lifetime at } \\
90 \% \\
\text { reliability } \\
\text { (years) }\end{array}$ & Subassembly & $\begin{array}{l}\text { Remaining } \\
\text { lifetime at } \\
90 \% \\
\text { reliability } \\
\text { (years) }\end{array}$ & Subassembly & $\begin{array}{c}\text { Remaining } \\
\text { lifetime at } \\
90 \% \\
\text { reliability } \\
\text { (years) }\end{array}$ & Subassembly & $\begin{array}{c}\text { Remaining } \\
\text { lifetime at } \\
90 \% \\
\text { reliability } \\
\text { (years) }\end{array}$ \\
\hline$B \& P$ & $\begin{array}{c}\text { Occurred } \\
\text { once }\end{array}$ & $B \& P$ & 12.5 & $B \& P$ & $\begin{array}{c}\text { Occurred } \\
\text { once }\end{array}$ & $B \& P$ & 53.5 \\
\hline $\begin{array}{l}\text { OC - } 3 \text { years } \\
\text { study period }\end{array}$ & 16.5 & OC & 8 & $\begin{array}{l}\text { OC - } 6 \text { years } \\
\text { study period }\end{array}$ & 6.5 & $\mathrm{OC}$ & 8.25 \\
\hline $\begin{array}{l}\text { EFP - } 4 \text { years } \\
\text { study period }\end{array}$ & 20.25 & EFP & 5.5 & $\begin{array}{l}\text { EFP - } 4 \text { years } \\
\text { study period }\end{array}$ & 52.5 & EFP & 26.5 \\
\hline $\begin{array}{l}\text { DP - } 4 \text { years } \\
\text { study period }\end{array}$ & 20.25 & DP & 15.5 & $\begin{array}{l}\text { DP - } 6 \text { years } \\
\text { study period }\end{array}$ & 23.5 & DP & 23.25 \\
\hline $\begin{array}{c}\text { B\&D - } 4 \\
\text { years study } \\
\text { period }\end{array}$ & $\begin{array}{c}\text { This failure } \\
\text { is constant } \\
\text { at } 30 \text { years } \\
\text { TBF }\end{array}$ & $B \& D$ & 10 & $\begin{array}{c}\text { B\&D - } 4 \\
\text { years study } \\
\text { period }\end{array}$ & 28.5 & $B \& D$ & 30.5 \\
\hline $\begin{array}{l}\text { FFS - } 6 \text { years } \\
\text { study period }\end{array}$ & 10.5 & FFS & 26.5 & FFS & $\begin{array}{l}\text { Occurred } \\
\text { once }\end{array}$ & FFS & 96.5 \\
\hline HS & $\begin{array}{l}\text { No failures } \\
\text { occurred }\end{array}$ & HS & 18 & HS & No failures & HS & No failures \\
\hline $\begin{array}{l}\text { Leakage - } 3 \\
\text { years study } \\
\text { period }\end{array}$ & 11.25 & Leakage & 13.75 & $\begin{array}{l}\text { Leakage - } 2 \\
\text { years study } \\
\text { period }\end{array}$ & 24.75 & Leakage & No failures \\
\hline FO & $\begin{array}{l}\text { No failures } \\
\text { occurred }\end{array}$ & FO & 38 & FO & No failures & FO & No failures \\
\hline Ol & $\begin{array}{l}\text { No failures } \\
\text { occurred }\end{array}$ & $\mathrm{Ol}$ & 15 & $\begin{array}{l}\text { Ol - } 5 \text { years } \\
\text { study period }\end{array}$ & 12.75 & Ol & 5.75 \\
\hline BBP & $\begin{array}{l}\text { Occurred } \\
\text { once }\end{array}$ & BBP & 10 & BBP & $\begin{array}{l}\text { Occurred } \\
\text { once }\end{array}$ & $\begin{array}{c}\text { BBP - } 7 \\
\text { years study } \\
\text { period }\end{array}$ & 84.5 \\
\hline $\begin{array}{l}\text { BW - } 2 \text { years } \\
\text { study period }\end{array}$ & $\begin{array}{c}\text { This failure } \\
\text { is constant } \\
\text { at } 30 \text { years } \\
\text { TBF }\end{array}$ & BW & 29.5 & BW & $\begin{array}{l}\text { Occurred } \\
\text { once }\end{array}$ & $\begin{array}{l}\text { BW - } 7 \text { years } \\
\text { study period }\end{array}$ & 134 \\
\hline$A \& B$ & $\begin{array}{l}\text { No failures } \\
\text { occurred }\end{array}$ & $A \& B$ & 75 & $\begin{array}{l}\text { A\&B - } 4 \text { years } \\
\text { study period }\end{array}$ & 40.5 & $\begin{array}{l}\text { A\&B - } 7 \text { years } \\
\text { study period }\end{array}$ & 184 \\
\hline $\mathrm{HM}$ & $\begin{array}{l}\text { No failures } \\
\text { occurred }\end{array}$ & HM & 26 & $\mathrm{HM}$ & $\begin{array}{l}\text { Occurred } \\
\text { once }\end{array}$ & $\mathrm{HM}$ & 188 \\
\hline $\begin{array}{l}\text { NF - } 2 \text { years } \\
\text { study period }\end{array}$ & 13 & NF & 17 & NF & $\begin{array}{l}\text { Occurred } \\
\text { once }\end{array}$ & NF & 72.5 \\
\hline $\begin{array}{c}\text { Others - } 6 \\
\text { years study } \\
\text { period }\end{array}$ & 9.25 & Others & 10.25 & $\begin{array}{c}\text { Others - } 2 \\
\text { years study } \\
\text { period }\end{array}$ & 15.5 & Others & 85.5 \\
\hline
\end{tabular}




\section{REFERENCES}

[1] M. Abdelfatah , M. El-Shimy, and H.M. Ismail. "Outage data analysis of utility power transformers based on outage reports during 2002-2009," International Journal of Electrical Power \& Energy Systems, vol. 47, pp. 41-51, May, 2013.

[2] M. Abdelfatah , M. EL-Shimy, and H.M. Ismail. "Reliability and maintainability analysis of medium voltage transformers in Egypt," in The 8th International Conference on Electrical Engineering (ICEENG-8) of the Egyptian Military Technical College, Cairo, Egypt, 2012, pp. 1-17.

[3] M. EL-Shimy , M. Abdelfatah , and H.M. Ismail. "Reliability, availability, and maintainability (RAM) analysis of utility power transformers in Egypt," ELEKTRIKA-UTM Journal of Electrical Engineering, Vol. 14, no. 1, pp. 1-5, Jan. 2012.

[4] Life Data Analysis erence, ReliaSoft Corporation [On-line] Available: http://www.ReliaSoft.com [Jan. $5,2018]$.

[5] R.B. Abernethy, J.E. Breneman, C.H. Medlin, G.L. Reinman. Weibull analysis handbook. Pratt and Whitney West Palm beach $\mathrm{fl}$ Government Products, DIV, 1983.

[6] W.B. Nelson. Applied life data analysis. Place of publication: John Wiley \& Sons, 2005.

[7] C. Forbes, M. Evans, N. Hastings, and B. Peacock. Statistical distributions. Place of publication: John Wiley \& Sons, 2011.

[8] Life Data Analysis erence, ReliaSoft Corporation [On-line] Available: http://www.ReliaSoft.com [ Jan 5, 2018].

[9] Oracle help center [online] Available: https://docs.oracle.com/cd/E12825_01/epm.111/ cb_user/frameset.htm?apas04.html [Jan 5, 2018].

[10] W.G. Ireson, C.F. Coombs, R.Y. Moss. Handbook of reliability engineering and management. Place of publication: McGraw-Hill Professional, 1996.

[11] J. Mun. Advanced analytical models: Over 800 models and 300 applications from the Basel II accord to Wall Street and beyond. Place of publication: John Wiley \& Sons, 2008,, appendix C.

[12] Online Help Manual, MATLAB Cooperation [Online] Available:

https://www.mathworks.com/help/stats/rayleighdistribution.html [Mar. 3, 2018].

[13] R.B. Abernethy. The New Weibull handbook: Reliability and statistical analysis for predicting life, safety, supportability, risk, cost and warranty claims. North Palm Beach, FL: Dr. Robert B. Abernethy, 2004.

[14] D. Martin, J. Marks, T.K. Saha, O. Krause, and N. Mahmoudi. "Investigation into modeling Australian power transformer failure and retirement statistics," IEEE Transactions on Power Delivery, vol, 33, no. 4, pp. 2011-9, Aug. 2018.

[15] Online Help Manual, MATLAB Cooperation [Online] Available:

https://www.mathworks.com/help/stats/wblfit.html [Mar. 3, 2018].

[16] Online Help Manual, MATLAB Cooperation [Online] Available:

https://www.mathworks.com/help/stats/weibulldistribution.html [Mar. 3, 2018].

[17] A.D. Telang, V. Mariappan. "Hazard rate of Lognormal distribution: An investigation," International Journal of Performability Engineering, vol. 4, no. 2, pp. 103, Apr. 2008.

[18] M.F. Aly, I.H. Afefy, R.K. Abdel-Magied, and E.K. Elhalim, "A comprehensive model of reliability, availability, and maintainability (RAM) for industrial systems evaluations," JJMIE, vol. 12, no. 1, pp. 59-67, Jun. 2018.

[19] S. Verbrugge, D. Colle, P. Demeester, R. Huelsermann, and M. Jaeger. "General availability model for multilayer transport networks," in DRCN 2005. Proceedings. 5th international workshop on design of reliable communication networks, IEEE, Oct. 2005, pp. 85-92. 
[20] E. Vargas. "High availability fundamentals.", Sun Blueprints series. 2000 Nov: 1-7. California, USA Nov.2000, pp. 1-17.

[21] P. Jarman, R. Hooton, L. Walker, Q. Zhong, T. Ishak, and Z. Wang. "Transformer life prediction using data from units removed from service and thermal modelling," in Proc. CIGRE Session, 2010, pp. 1-7.

[22] P. Jarman, Z. Wang, Q. Zhong, and T. Ishak, "End-of-life modelling for power transformers in aged power system networks," in CIGRE 2009 6th Southern Africa regional conference, Cape Town, Southern Africa, 2009 Aug 17, pp.1-7.

[23] Bureau of RECLAMATION "Transformers: Basics, maintenance and diagnostics,", US Department of the Interior Bureau of Reclamation. Denver, Colorado, USA. Apr. 2005.

[24] J.H. Harlow. "Electric power transformer engineering,", CRC press; New York, USA, Dec. 2011 